\title{
The impact of mediatisation in the healing ministry of African preachers
}

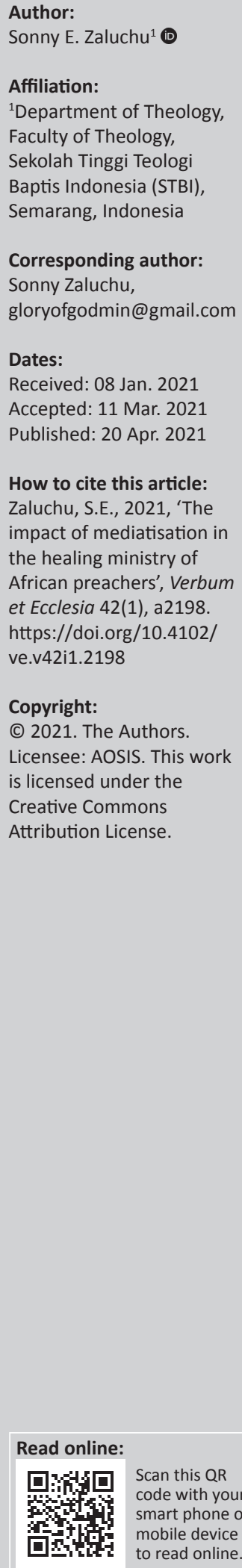

Healing service happens everywhere. However, the healing service practice in Africa, as practised by several preachers from South Africa, Nigeria, Malawi and Zimbabwe, is more phenomenal and has a significant impact towards the Christianity in the world. One of the impacts is the emergence of religious tourism. This study observes that the service success is supported by two things, namely a deep understanding and the strong foundation on the theology of biblical healing, which trigger the presence of faith, on the one hand, and on the other hand the presence of invisible but very real support from the power of media popularising this practice to all over the world. It is concluded that even though it must be tightly controlled, mediatisation is an adaptive step to introduce the mission of the church and news related to the Bible to the modern society. Christianity has to accept this step as the updated step.

Intradisciplinary and/or interdisciplinary implications: This article takes an interdisciplinary and multidisciplinary approach to media's role and uses in today's Christian ministry. The presence of the media and its optimisation for evangelism are supported by global theology.

Keywords: mediatisation; religion; divine healing; African healers; Christian ministry; media; spirituality.

The divine healing service conducted by the Pentecostal-Charismatic Christian churches and the priests in Nigeria, South Africa, Malawi and Zimbabwe (Fröhlich 2019), provides not only regional but also global impacts. The Christians from Asia, Australia, Europe, West and from African regions join the pilgrims to visit various points as the places carrying out the divine healing religious services in several regions of Africa. Tents and rooms of such activities are always full, and sick people flock to visit those places that are known for a speedy recovery. The service becomes phenomenal because it is considered to be related with miracle, healing, deliverance from the power of darkness, the touch of God and the rendering of the supernatural prophetic messages. However, there are a number of criticisms in their ministry such as the inaccuracy of prophecy (All Africa 2015).

According to Bremer's (2006) analysis, theexistence of a healing ministry that displays a demonstration of God's power has succeeded in presenting a sacred space so that it becomes an attraction for spiritual pilgrimages. Pentecostal-Charismatic Christian churches' large role in organising various healing events (Hovi 2018) has also helped promote similar activities in several African countries as spiritual tourism destinations (Nyikana 2017) for people who want to seek healing.

The popularity of God's power demonstration in various religious festivals in Africa globally can encourage interest and curiosity particularly in terms of the source of power and the validity of its theology. This is very reasonable considering that Africa and its culture are also known to be strong in traditional healing involving shamans, mantras, incantation, magic, certain items and rituals. There is parallelism between faith healing practice in Christian and the tradition based on the local wisdom.

The nonmedical healing practice phenomenon in Africa was once reviewed in the research conducted by Berends (1993). The research results conclude that Africa's traditional healing practice actually resembles various healing events as discussed in the Bible. Even Berends firmly concluded that those practices close the gap in healing and recovery that cannot be performed by modern medicine. Therefore, the ways of treatment and healing practised by the churches in Africa are categorised as alternative treatment packaged in the preaching of the commandment of God to raise faith.

A temporary answer appears from the thesis written by Grundmann (2015). his research concludes that the key factor bringing in the supernatural power in such service is faith. In other words, healing and faith are the most significantly and mutually correlated variables. The faith concept 
such as this has also been researched by Sarkar et al. (2014) who attempted to observe the medical practice outside the perspective of Christian faith from the East. The results of their research in the traditional healing practice in the South Asian region show a similar pattern. The faith factor in a number of traditional medicines involving talisman, items, prayers and certain rituals is very significant. Therefore, it is obvious that faith is the key factor of nonmedical healing, traditionally both in various cultural forms and in the Christian divine healing activities.

Interestingly, the popularity of divine healing service practice in Africa is not only supported by the presence of the spiritual aspect, which in this case is the faith of a believer, but this popularity also lies in the immense power of the media. The spread of religious healing activities throughout the world is a synergy between the church and pastors and the media. Oluwafemi's (2019) research concluded that the church attendance in public spaces takes place through the use of various information and media facilities known to the public. Mateus (2017) reinforces this argument and examines the relationship between the media and the church. According to him, the media significantly influences disseminating information and church activities to the public.

Based on that fact, it is interesting to research further how faith and media play a role, which is mutually complementary in the divine healing service activity in Africa. This article attempts to discuss and build argumentation to defend the healing movement in Africa as the implementation of the healing theology in a practical level, but it is developed contextually on the one hand and presented in an interesting package with the involvement of media on the other hand. Both of these aspects become the support of the contemporary Christian healing service. If it is analogised as a pillar, the theology of healing becomes the pillar to explain divine healing, whilst media becomes another pillar that brings divine healing to the public space. The elaboration in this article will discuss these two aspects: firstly, the article will discuss the typical theology of healing, and secondly it will discuss the aspect of media's role in the service. The latter part adds a number of critical points towards the effort of mediatisation in the Christian ministry.

\section{Healing perspective in theology}

Healing in the Christian theology is always related to two things, namely the supernatural power (the divine aspect) and faith as the aspect of Christian belief (eds. Ryken, Wilhoit \& Longman 2011:942). Both of these aspects are parallel because the Christians believe epistemologically that only God is capable of performing miracles of healing to everyone (Colle 2011). In the Christian perspective, the supernatural power is believed to come from God himself and not from natural forces, magic or mantra coming from humans or the practice of a cultural tradition. Therefore, in the Christian healing practice, the church and/or God's servants are present as the bridge to accept and experience the power. They are not shamans or the ethnic religious figures or people having affiliation with a certain cultural rite. The first difference lies in the source of power. The Bible supports that. One of the chapters in the Bible explains how Jesus gave the power and ordered his disciples to preach good news (Keener 2014:70):

And as ye go, preach, saying, the kingdom of heaven is at hand. Heal the sick, cleanse the lepers, raise the dead, cast out devils: freely ye have received, freely give. (Mt 10:7-8)

The second significant difference is the purpose of the healing service itself. Christianity places two essential aspects of healing, namely recovery and soul outreach. God confirmed the gospel with signs and wonders as an open witness to awaken others' faith and make them believe in the good news of salvation. The liberation and recovery for salvation always appear in every service of Jesus and his teachings. The verse 'your faith has healed you' and its similar understanding occur many times in the notes of the Bible; the healing of a woman from bleeding (Mt 9:22); the blind who could see again (Mk 10:52); and the leper who recovered (Lk 17:19). Apart from the effects of changing cultural contexts and modernisation (Yang 1998), as an example, the success of evangelism in China is sustained by demonstrating God's power through miracles of healing represented by the evangelists (Oblau 2011).

In the context of Christianity, faith is the main key to experience miracle and healing and all other supernatural things recorded in the Bible. The Prophet Paul defines faith as the foundation of all that we expect and the evidence of all things that we cannot see (Heb 11:1). A theologian such as Keener (2014:658) interpreted this definition in the context of future rewards and the expectation for God's day. However, Hayford (ed. 1995:595) interpreted it in a different way. According to him, faith is a belief in or a confident attitude towards God, involving commitment to his will for one's life. Pawson (2015:1128) explained that in faith people choose to keep believing, although they never see what they believe in. Therefore, in the context of divine healing, faith can be seen as an unwavering belief essence to God, his acts, his action, his will and his design.

The healing of a woman from bleeding in the Bible is the best example to explain how faith works to guide human's deeds to finally lead to healing. The woman suffering from chronical bleeding said within herself, 'If I may but touch his garment, I shall be whole' (Mt 9:21). The words were uttered with faith and the woman moved into the crowd surrounding Jesus and touched him from below (Lk 8:44-48). Power flowed from Jesus to the woman, healing her and recovering her identity (Shaw 2020). This event shows that faith encourages human's heart to act and take a step as he or she believes in. As experienced by the woman, her faith guided her to act and eventually it became a way in for her to accept God's power.

The characteristic such as this is always found in the healing service. After someone has been prayed for, the person is expected to act based on faith, to do something that he or she was not capable of before. Someone who is present with a 
crutch is requested to let go the crutch and walk with his or her own power. Someone sitting in a wheelchair is asked to walk leaving his or her wheelchair. Someone who has a back strap is asked to let it go whilst moving his or her body around. In this case, it is seen that the power of faith cannot be in line with logic and common sense (Tavani 2008; Wilson 2002). Medical professionals believe it is ridiculous that a priest, for example, asks another to release his or her back strap for a broken backbone. However, that is how the healing practice works according to the perspective of Christian faith. It will not give space and room for doubts and disbelief. Wilson (2014) asserted that the systematics and methodology of such practice do refer to the events and methods as they happened before and are mentioned in the Bible. The sick people came, Jesus prayed for them and the healing occurred instantly. The methodology is contrary to how science-based medicine works and observation (Coyne 2015:65). Hence, these two approaches cannot be collided. Nevertheless, these two can strengthen each other. Healing with a spiritual way is a divine healing, and it is natural, but the results can be proved with medical confirmation (Mathew 2018). The process cannot be reversed.

The theology of healing in Christian's perspective is built on the premise that spiritual healing is the result of the supernatural power of God amongst humans. The holy book of Christians provides notes on that matter completely (Clayton 2011). The statement of Elohim as God that heals (Jehovah Rapha) in the Old Testament (Ex 15:26) refers to the premise verification, as also proved in the service of Jesus in the New Testament (Mouton 2016). This premise seems to provide the colour of theology in the divine healing practice in Africa. Its development is directed towards the effort to present the real Christ in providing solutions and healing in a wider socio-cultural context (Nell 2011). In other words, Christology becomes the strong root and foundation for healing itself.

Such a service model is considered relevant for Africa's situation because the theology of healing is directed more to the practical approach than to the philosophical approach. It is called practical because theology becomes the entrance for evangelism and the effort to introduce Christ. As a result, healing became a way of proving the Bible's truth and making it real so that Africans believed that Christ was amongst them. The final objective is a conversion that makes them a new man in Christ and frees them from contextual suffering. Magezi and Magezi (2016) call this Adamic Christology because it makes African people new Adams freed from chains. We have to realise that African society has grown in solid traditions and cultural heritage. Christianity must work hard to infiltrate various cultural approaches and traditions that have been attached all this time in the world view of the Africans on healing. Supernatural power is not something foreign there. Introduction to this power has grown in traditions and the ethnic religion-based belief system and ancient rituals preserved from one generation to another as a pearl of local wisdom. Christianity is present in the midst of the situation to introduce another source of power, which also brings healing. The difference lies in the source of power.

The theology of healing in Africa as practised all this time can be seen in the conclusion made by Nwuzor (1997) in his doctoral research on African Christology, and it is stated that the role of Christ presented in the African terminology relies on three identities, namely Christ as a liberator, Christ as a healer and Christ as a savior. All three become one existential package in the African healing theology. In almost all healing services practised, people have experienced manifestation because they are freed from the binding of the dark power, they accept healing and they decide to live a new life in Christ.

\section{The influence of mediatisation}

The effort to introduce healing service from Africa to the world cannot be separated from the role of media, which is used for the purposes of promotion and socialisation (Dole 2006). This can be observed by looking at the profile and public performance shown by the preachers of healing. They realise two things, namely the appearance in front of camera and the media effect, which can become the catalyst in pursuing publicity and popularity. This realisation generally develops amongst the priests of Africa who are the Pentecostal and Charismatic followers. They master the air space of Africa and have a big number of congregations (Ihejirika 2009). Therefore, media involvement becomes one of the inclusion factors of various healing prayers and praying activities in Africa. Through media, a preacher, on the one hand, is presented in the function and true identity as the servant of the Lord. However, a preacher, on the other hand, is formed in an image as a public figure (a famous person). This uniqueness is identified in a number of characteristics and arrangements that can be traced as the camera-aware effect. The arrangements include the mode and style of a unique clothing of the preacher, the narration delivered, the appearance in the podium, direct interaction amongst the congregations, the presence of the guards, catchers and ushers that always accompany the activity, the presence of the person holding the microphone and the existence of the narrator assigned to cheer up the situation. Even the camera angle also builds a dramatic situation by following the footsteps of the preacher. The recording model is designed to look like a reality show. All this combination is integrated in one media broadcasting product package so that the publication effect that can attract audience can be created and it raises hopes/faith from those who listen to or see it or get involved in the show. According to Mwale (2018), this is not a new idea because the African traditional healers have done it first in the public sphere to promote their activities. Thus, when the priests do a similar thing, this divine healing publication is easily accepted by the society.

The influence of media in the Christian service is part of awareness towards the beneficial era development. Digital technology has taken over the information socialisation functions amongst society (Potgieter 2020). People depend 
more on television (TV), websites, social media, internet network and Christian service computers searching for information. For example, $86 \%$ of the world's population have used the Google platform as a search engine (Davies 2021). This becomes a characteristic in the society moving forward in terms of information technology. Important shifts happen with the formation of a believer group in the digital communities amongst the society, such as Christian rituals, holy book discussion and delivering preaches, activities and social relations, community support towards the service and other religious practices mediated by computer (Hutchings 2011). The landscape of Christianity has been shifted from the conventional behaviour based on the building for praying to the digital practice run online and involving online visitors. The social change in religion has happened (Crumpton 2018). Digital media is involved because it is proved to be effective in spreading religious information. Facebook, Tweeter and Instagram can become the influential means to deliver information to the digital congregations because almost all people have social media accounts (McKinney 2014). The media service will even be able to reach people who cannot be present directly in various spiritual activities because of the limitations of space, distance and time.

Mediatisation is an effort to make everything presented and become media products. In this case, media becomes the tool to influence and form the opinions of many people (Triputra 2017). The power lies in the capability of the media management and the packaging for public interest (Bogešić 2019). In the socio-cultural landscape of modern society, information is completely controlled by media (Finnemann 2011). Almost all human activities in the contemporary world are the interaction results with media. From obtaining information to obtaining answers of life needs socially, politically, economically, artistically, culturally and spiritually, media manages to plant its influence and create dependence (Hepp, Hjarvard \& Lundby 2015). In the contemporary society nowadays, media becomes some kind of hub, between humans and reality. Therefore, it can be said that mastery and management of media can encourage service to the highest publication point.

The opportunity to use media in its functions and role to bridge communication with the society is seen very strong in the divine healing service in Africa. Television broadcast and digital content are the two products that always overshadow and support the divine healing service. Almost all preachers and the institutions holding events have a TV channel, a radio channel and digital content in YouTube. The awareness towards the importance of media has become the vehicle to reach popularity, on the one hand, and to promote the activities on the other hand. In other words, mediatisation is the answer key explaining why the divine healing services in Africa are successful to become a new mainstream in the service of Christianity in the world. What has been done there is in accordance with the theory and analysis on the role of media to do agenda setting. Eriyanto stated that media in the concept of agenda setting will be able to determine what is considered important by public (Eriyanto 2018:10).
The divine healing activities in an agenda setting by media are promotion, popularity and information control. It is not surprising that if all over the world eventually the servants of the Lord in Africa who are identical as the personnel who bring healing power are eventually recognised. However, in the Christian theology, everybody believes anyone wherever and whenever will be able to bring the same power.

\section{Critical points}

Nevertheless, although beneficial in many things, there are opposing sides of media involvement that are inevitable. Several critical points that require attention, explanation and improvement so that the purity of Christian service can be still maintained are as follows.

The first is the dependency of a service product on media logic. In the perspective of marketing, media always orients towards acts to control and influence. Media cooperates with the people working with technology to carry out marketing (Kitchen \& Proctor 2015). Such logic will happen naturally when the media starts to be involved in the religious service. The shift of control and influence from the ministry-centred to media-centred will occur slowly without people being aware of it. Media and religious service have different purposes. The media focusses on the marketing interest only towards the products offered, whereas the religious service is for the spiritual part. If those two purposes are not synchronised, what will happen is media will slowly make the religious service a product that has to penetrate and pursue the market.

Consequently, the religious service will be controlled and forced to follow the media logic orienting to the commercial, entertainment, rating and segmentation of market needs. The Lord's servants will eventually get trapped to maintain the religious service for the sake of rating, to be at the peak of the competition of a similar religious service by another party, to have the financial benefits flowing through offerings, commercials and other materialistic items. The trap of fame also becomes the catalyst in encouraging the birth of power and miracle engineering. God's commandments become trading products and have the potential to be manipulated to support the commercial interest. However, what is more dangerous is the fear (Comiskey 1985, as cited in the research of Mateus 2017). Media has given humans ideas that they are strong, and with that a belief will grow that they do not need to seek God and the church as they only rely on the supernatural power of the healing preachers. Television and its set of shows become more important than the altar and the presence in the church. The instant things become solutions to refuse following every process that God may let happen. New narrations are created, regardless of whether they contain the truth or not, from the Bible. They might even be manipulated for media interest, so they can be entertaining and delightful to be heard by the audience (Lövheim 2014). Content is prepared to answer the segmentation of the market, not to fulfil the spiritual mission. 
The second is the shift of the theological centre. Media framing in the healing service will create two kinds of sentiments that are contradictory to each other. The positive sentiment towards the main actors becomes more potent as the opinion amongst the society. However, there is a negative sentiment towards the medical healing method. The study conducted by Wilkens (2018) stated that medical denial towards spiritual healing has the potential to strengthen the existence of spiritual healing as an alternative healing method. The fact becomes the preacher's foundation to provoke sick people to pursue their recovery through divine healing as the last resort when medicine fails to handle them.

Framing has also managed to position the preachers to the service centre point so that without their being aware of it, people look up at those preachers more than Jesus and his power. The healing service is not the end goal and only functions as the tool of confirmation in God's preaching of commandments. Media has caused the shift of the theological centre from Jesus-centred, which is what it should be, to become human-centred. People are brought not to God but to humans being praised as the ones having the power. Exclusivism in the healing service frequently starts from something like this. Jesus never made his service exclusive just because he was the healer and miracle doer. Although he realised that not everyone liked him, Jesus served without any guards, embraced everyone from various community classes, was present without the media attribute and socialised in the public sphere without limiting himself.

The third is the side effect of digitalisation. Healing service is designed with interaction in a community. However, with media presence in the service, people become more individual and do not become part of a community. The congregation's response towards that natural characteristic is reduced through a new environment consisting of a computer, internet connection and digital application. The early congregations in the Acts of the Apostles were not like that. The first Christian community experienced a breakthrough in many things when they were bound in one community (Zaluchu 2018).

On the contrary, in the digital world, the function of the community is dismissed. People will think that it is sufficient to watch a TV show or YouTube channel and divine healing happens. Imagination such as this is always present on behalf of faith. The service shifts from the too much reliance on the current participants in a praying event to a passive model where the congregations only sit silently watching the presentation and the show (Lewis 2016).

Consequently, many Christians do not experience real spiritual growth, as they only share the illusion. They will finally believe in the idea that what is happening online is the divine reality in the modern era, which is identical with the notes of the Bible's writers on the healing service of Jesus in the Bible. Media can eventually be misunderstood as the
Temple in Jerusalem (Jacobson et al. 2016). Meanwhile, God does not exist and linger in media.

The fourth is the presence of instant faith in a wrong address. Faith is built from the in-depth intensity with God through a growing spiritual life. Faith never appears instantly. Faith is part of the religious process and a deep understanding towards God (Herrman 2009). The preachers of healing are not Jesus who could do everything as easy as turning your hand and those preachers cannot take Jesus' position. Christian epistemology firmly states that divine healing results from faith in Jesus, not to the shamans, humans or preachers of healing (Grundmann 2015).

Blow-up media towards healing service can lead to the presence of instant faith working outside of the Christian epistemological principle. A side effect is that the Christians believe that everything related to miracles and healing can be obtained instantly only by attending a Christian revival event or a praying event as promoted via TV or social media. The Christians must be educated that healing is not available on YouTube, TV and various other digital channels. Awareness of the transcendent God cannot be manifested digitally. The power of God is inherent in faith and belief and does not have a place in media.

\section{Conclusion}

The strength of healing service in Africa is supported by the strong practice and a deep understanding of the theology of healing presented by the church and the priests serving that calling. The epistemic claim on Jesus and divine healing has managed to be practised as the traditional healing competitor. Thus, when people need healing, they do not seek it in the cultural concept or local wisdom (shamans or through certain rituals or talisman and incantation). The church and priests have become the representations of divine healing and deliverance in Christ.

The role of media in promoting healing services in Africa is very significant. The media has managed to bring healing service in Africa and its figures become internationally well known and reach certain popularity. A Christian service mediatisation is an option that cannot be avoided currently in response to the world change shifting to the era of digitalisation and technology. The church and various service institutions, including the Lord's servants, need to involve themselves and adapt to the media service like what happens in Africa. The method to deliver it and the way to present Christ in the world need to be readapted following the era dynamics. The Internet and technology are available now as the vehicle. The church and the servants of the Lord cannot feel allergic to all this change. As long as Christian epistemology can be guarded and maintained, media will only become a tool for the interest of Christianity itself. Healing service mediatisation in Africa should be the inspiration for global (religious) service, even though it is realised that strict control in maintaining the basic value of Christian is still required. 


\section{Acknowledgements}

The author would like to acknowledge Dr Robinson Rimun, MTh, president of the Indonesia Baptist Theological Seminary, for extending his moral support to this research.

\section{Competing interests}

The author declares that no competing interest exists and there is no financial or personal relationship that may have inappropriately influenced him in writing this article.

\section{Author's contributions}

The author declares that he is the sole author of this research article.

\section{Ethical considerations}

This article followed all ethical standards for a research without direct contact with human or animal subjects.

\section{Funding information}

The author received no financial support for the research, authorship and/or publication of this article.

\section{Data availability}

Data sharing is not applicable to this article as no new data were created or analysed in this study.

\section{Disclaimer}

The views and opinions expressed in this article are those of the author and do not necessarily reflect the official policy or position of any affiliated agency of the author.

\section{References}

All Africa, 2015, African prophets \& their 2015 prophecies that never occurred, viewed 08 March 2021, from Allafrica.com.

Berends, W., 1993, 'African traditional healing practices and the Christian community' Missiology: An International Review 21(3), 275-288. https://doi.org/10.1177/ 009182969302100301

Bogešić, R. 2019. 'The Church and the Media', Kairos 13(1), 107-120. https://doi. org/10.32862/k.13.1.4

Bremer, T.S., 2006, 'Sacred spaces and tourist places', in D.J. Timothy \& D.H. Olsen (eds.), Tourism, religion and spiritual journeys, 1st edn., pp. 25-35, Routledge, New York, NY.

Clayton, P., 2011, 'The theology of spiritual healing', in F. Watts (ed.), Spiritual healing: Scientific and religious perspectives, pp. 44-63, Cambridge University Press, Cambridge.

Colle, R.D., 2011, 'Miracles in Christianity', in G.H. Twelftre (ed.), The Cambridge companion to miracles, pp. 235-253, Cambridge University Press. https://doi. org/10.1017/CCOL9780521899864.014

Coyne, J.A., 2015, Faith vs fact, Penguin Random House LLC, New Yok, NY.

Crumpton, V.E., 2018, 'The church has left the building: A leadership perspective of online church versus traditional church', PhD thesis, Portland Seminary, George Fox University, Portland, OR.

Davies, D., 2021, Meet the 7 most popular search engines in the world', Search engine journal (SEJ), viewed 7 March 2021, from https://www.searchenginejournal.com/ seo-101/meet-search-engines/\#close

Dole, C., 2006, 'Mass media and the repulsive allure of religious healing: The Cinc Hoca in Turkish modernity', International Journal of Middle East Studies 38(1), 31. https://doi.org/10.1017/S0020743806412241
Eriyanto, 2018, Media dan Opini Publik [Media and public opinion], 1st edn., Rajawali Pers, Depok.

Finnemann, N.O., 2011, 'Mediatization theory and digital media', Communications, 36(1), 67-89. https://doi.org/10.1515/comm.2011.004

Fröhlich, S., 2019, 'Africa's self-styled prophets and their "miracles"', Deutsche Welle, viewed 06 March 2020, from https://www.dw.com/en/africas-self-styled-prophets-and-their-miracles/a-47764493

Grundmann, C.H., 2015, 'Faith and healing - What faith-healing is about, with special reference to the Christian tradition', Irish Theological Quarterly 80(3), 233-247. reference to the Christian tradition', Irish The
https://doi.org/10.1177/0021140015583248

Hayford, J. (ed.), 1995, Hayford's Bible handbook, Thomas Nelson, Nashville, TN.

Hepp, A., Hjarvard, S. \& Lundby, K., 2015, 'Mediatization: theorizing the interplay between media, culture and society', Media, Culture \& Society 37(2), 314-324. https://doi.org/10.1177/0163443715573835

Herrman, C.S., 2009, 'When Is Faith a Religion? Part I: The Four Criteria', SSRN e-Library. https://doi.org/10.2139/ssrn.1358450

Hovi, T., 2018, 'Faith healing revisited: A charismatic Christian intervention to the therapy culture in Finland', in J. Moberg \& J. Skjoldli (eds.), Charismatic Christianity
in Finland, Norway, and Sweden, pp. 161-186, Springer International Publishing, in Finland, Norway, and Sweden, pp. 161-186, Springe
Cham. https://doi.org/10.1007/978-3-319-69614-0_7

Hutchings, T., 2011, 'Contemporary religious community and the online church', Information Communication \& Society 14(8), 1118-1135. https://doi.org/10.1080 /1369118X.2011.591410

Ihejirika, W., 2009, 'Research on media, religion and culture in Africa: Current trends and debates', African Communication Research 2(1), 1-60.

Jacobson, H.L., Hall, M.E.L., Anderson, T.L. \& Willingham, M.M., 2016, 'Temple or prison: Religious beliefs and attitudes toward the body', Journal of Religion and Health 55, 2154-2173. https://doi.org/10.1007/s10943-016-0266-z

Keener, C.S., 2014, The IVP Bible background commentary-New Testament, 2nd edn., IVP Academic, Downer s Grove, IL.

Kitchen, P.J. \& Proctor, T., 2015, 'Marketing communications in a post-modern world', Journal of Business Strategy 36(5), 34-42. https://doi.org/10.1108/JBS-06-2014-0070

Lewis, B., 2016, How social media is changing the church, The Conversation.

Lövheim, M., 2014, 'Mediatization and religion', in S. Hjarvard \& M. Lövheim (eds.), Mediatization of communication, pp. 547-570, De Gruyter, Berlin, viewed 15 December 2020, from https://www.grin.com/document/424268.

Magezi, V. \& Magezi, C., 2016, 'Pastoral care and healing in Africa: Towards an Adamic Christological practical theology imagination for pastoral healing', HTS Teologiese Studies/Theological Studies 72(2), a3467. https://doi.org/10.4102/ hts.v72i 2.3467

Mateus, E., 2017, The media and the church, pp. 1-28, GRIN Verlag.

Mathew, B., 2018, 'Divine healing and medicine', SSRN e-Library. https://doi. org/10.2139/ssrn.3270094

McKinney, D., 2014, 'Social media in the church', PhD thesis, University of Arkansas, Arkansas.

Mouton, E., 2016, 'Jesus as healer in the Gospel of Matthew: In conversation with Alan Culpepper', In die Skriflig/In Luce Verbi 50(1), a2143. https://doi.org/10.4102/ids. v50i1.2143

Mwale, N., 2018, 'African Traditional Healers in the Media in Zambia's Contemporary Times', Zambian Journal of Religion and Contemporary Issues, 1(1), 1-21. https:// www.researchgate.net/publication/336315111_African_Traditional_Healers_in www.researchgate.net/publication/336315111_.

Nell, I.A., 2011, "Practical theology as "healing of memories": Critical reflections on a specific methodology', HTS Teologiese Studies/Theological Studies 67(2), a1001. https://doi.org/10.4102/hts.v67i2.1001

Nwuzor, D.N., 1997, 'A survey of African Christology', PhD thesis, Universidad de Navarra, Pamplona, Spain.

Nyikana, S., 2017, 'Religious tourism in South Africa: Preliminary analysis of a major festival in Limpopo', African Journal of Hospitality, Tourism and Leisure 6(1), 1-8.

Oblau, G., 2011, 'Divine healing and the growth of practical Christianity in China', in C.G. Brown (ed.), Global Pentecostal and charismatic healing,
pp. 307-325, Oxford University Press. https://doi.org/10.1093/acprof: pp. 307-325, Oxford Unive
oso/9780195393408.003.0016.

Oluwafemi, M., 2019, Effect of social media on the church, pp. 1-34, viewed 08 March 2021, from Afribary.com

Pawson, D., 2015, Unlocking the bible, 3rd edn., William Collins, London.

Potgieter, A., 2020, 'Digitalisation and the church - A corporeal understanding of church and the influence of technology', STJ/Stellenbosch Theological Journal 5(3), 561-576. https://doi.org/10.17570/stj.2019.v5n3.a26

Ryken, L., Wilhoit, J.C. \& Longman, T. (eds.), 2011, Kamus Gambaran Alkitab [The Dictionary of biblical imagery], Penerbit Momentum, Surabaya.

Sarkar, S., 2014, 'Ethical issues relating to faith healing practices in South Asia: A medical perspective', Journal of Clinical Research \& Bioethics 5(4), 1-3. https:// doi.org/10.4172/2155-9627.1000190

Shaw, 2020, 'Restoring a hemorrhaged identity: The identity and impact of the bleeding woman in Luke 8:40-56', Bulletin for Biblical Research 30(1), 64. https:// doi.org/10.5325/bullbiblrese.30.1.0064

Tavani, H.T., 2008, 'The classic debate on the relationship between faith and reason: Some contemporary challenges from the perspectives of relativism and postmodernism', Insight: Rivier Academic Journal 4(1), 1-20.

Triputra, P., 2017, 'Mediasi dan Mediatisasi', Jurnal Komunikasi Indonesia 3(2), 1. https://doi.org/10.7454/jki.v3i2.8842 
Wilkens, K., 2018, “'Instant miracles are rare, but it happened to me"', Numen 65(2-3), 207-231. https://doi.org/10.1163/15685276-12341495

Wilson, J., 2002, 'The logic of faith', Journal of Beliefs \& Values 23(2), 133-139. https:// doi.org/10.1080/1361767022000010798

Wilson, W.T., 2014, Healing in the Gospel of Matthew: Reflections on method and ministry, Fortress Press, PA.
Yang, F., 1998, 'Chinese conversion to Evangelical Christianity: The importance of social and cultural contexts', Sociology of Religion 59(3), 237. https://doi. org $/ 10.2307 / 3711910$

Zaluchu, S.E., 2018, 'Eksegesis Kisah Para Rasul 2:42-47 untuk Merumuskan Ciri Kehidupan Rohani Jemaat Mula-mula di Yerusalem', EPIGRAPHE: Jurnal Teologi dan Pelayanan Kristiani 2(2), 72-82. https://doi.org/10.33991/epigraphe. v2i 2.37 